\title{
SISTEMA AQUIFERO GUARANI - CONSIDERAÇÕES PRELIMINARES SOBRE A INFLUÊNCIA DO ARCO DE PONTA GROSSA NO FLUXO DAS ÁGUAS SUBTERRÂNEAS
}

\author{
Ernani Francisco da Rosa Filho ${ }^{1}$ \\ Eduardo Chemas Hindi ${ }^{1}$ \\ Sidnei Pires Rostirolla ${ }^{1}$ \\ Francisco José Fonseca Ferreira ${ }^{2}$ \\ André Virmond Lima Bittencourt ${ }^{1}$
}

\begin{abstract}
The Guarani Aquifer System (GAS) encompasses almost all the Paraná and Chaco-Paraná sedimentary basins area. Sandstones from the Pirambóia, Rosário do Sul and Botucatu Formations in Brazil and Misiones Formation in Paraguay and Tacuarembó Formation in Uruguay and Argentina constitute the reservoirs of the GAS. This study aims to evaluate geological and air born geophysical data in order to generate the GAS conceptual model that will permit to establish the main groundwater flow and thermodynamic reactions conditioning. The GAS underlies an area around $1.195 .000 \mathrm{~km}^{2}$. In the Parana State area, the aquifer clearly shows structural compartments limited by fractures filled with diabase dykes in consequence of the activation of the Ponta Grossa Arch. The same feature is supposed to occur in the areas of the Assunção Arch, Rio Grande Arch and Campo Grande Arch. In the diabase dykes vicinities the groundwater flows upwards discharging into the Serra Geral Aquifer as well as into the major drainage channels like the Iguaçu River. The Jurassic sandstone package on the top of the aquifer has an average porosity of $17 \%$ and hydraulic conductivity varying from 0,2 to $4,6 \mathrm{~m} /$ day. The Triassic sandstone package at the bottom has an average porosity of $16 \%$ and hydraulic conductivity varying from less than 0,01 to 4,6 $\mathrm{m} /$ day. The total volume of water stored in the aquifer is estimated in $46.280 \mathrm{~km}^{3}$ considering the average thickness of the aquifer as $228 \mathrm{~m}$. The most important GAS natural springs occur in areas with altitude below $400 \mathrm{~m}$, predominantly at the main drainage channels margins like the Paraná, Paranapanema, Iraí, Piquiri, Iguaçu and Uruguai Rivers. In those areas are placed important resorts that use natural springs whose waters flow in the surface with temperatures that reach till $43^{\circ} \mathrm{C}$ due to the aquifer geothermal properties.
\end{abstract}

\section{RESUMO}

O Sistema Aqüífero Guarani (SAG) abrange quase toda a área das Bacias Sedimentares do Paraná e Chaco-Paraná. As rochas-reservatório do SAG são os arenitos das Formações Pirambóia, Rosário do Sul e Botucatu, no Brasil, Misiones no Paraguai e Tacuarembó no Uruguai e Argentina. O presente estudo tem a perspectiva de avaliar dados geológicos e aerogeofísicos e assim dar início a uma investigação que permita projetar um modelo conceitual do SAG, sem o qual torna-se impraticável estabelecer os principais condicionantes que regem o movimento das águas subterrâneas e suas reações termodinâmicas. Este sistema aqüífero ocorre numa área de aproximadamente 1.195.000 $\mathrm{km}^{2}$ e está claramente compartimentado pelo Arco de Ponta Grossa, no Estado do Paraná, e apresenta indícios de similar compartimentação causada pelo Arco do Rio Grande, pelo Arco de Assunção e pelo Arco de Campo Grande. Em função da presença de feições tectônicas e de várias intrusões de rochas básicas e intermediárias, é junto dessas grandes estruturas que ocorrem as principais áreas de descarga do aqüífero, ascendendo para a superfície e recarregando a Formação Serra Geral, assim como desaguando nas grandes drenagens, como no rio Iguaçu próximo da sua foz. A parte superior do pacote arenoso, os arenitos do Jurássico, apresentam uma porosidade média de $17 \%$ e condutividade hidráulica da ordem de 0,2 a 4,6 m/dia. Os arenitos da parte inferior, do triássico,

\footnotetext{
${ }^{1}$ LPH - Laboratório de Pesquisas Hidrogeológicas - UFPR; Centro Politécnico - Jardim das Américas; cx postal 19001; CEP: 81531-990 Curitiba-PR, Brasil; e-mail: ernani@ufpr.br

2 LPGA - Laboratório de Pesquisas em Geofísica Aplicada - UFPR
} 
apresentam uma porosidade média de $16 \%$ e condutividade hidráulica inferior a 0,01 até 4,6 $\mathrm{m} /$ dia. O volume total de água no aqüífero foi estimado como sendo igual a $46.280 \mathrm{~km}^{3}$. Para este cálculo foi considerado $228 \mathrm{~m}$ como espessura média do sistema aqüífero. As principais surgências naturais do aqüífero estão localizadas em áreas com cotas inferiores a $400 \mathrm{~m}$, predominantemente margeando as principais drenagens da região, a exemplo dos rios Paraná, Paranapanema, Iraí, Piquiri, Iguaçu e Uruguai. É exatamente nestas regiões que estão localizadas as principais estâncias hidrotermais naturais, com temperaturas de até $43^{\circ} \mathrm{C}$.

\section{INTRODUÇÃO}

O Sistema Aqüífero Guarani (SAG) tem grande importância como fonte hídrica de alta qualidade para o suprimento de água potável, assim como para o aproveitamento de seu grau geotérmico.

O desenho do modelo conceitual deste aqüífero é fator primordial para delinear diretrizes que permitam 0 gerenciamento das águas armazenadas em suas rochas. Ao contrário do que anteriormente era considerado, o aqüífero não se distribui de forma homgênea em toda a sua extensão de ocorrência. Existem várias intrusões de rochas básicas $\mathrm{e}$ intermediárias, o que compartimenta o aqüífero principalmente nas áreas onde há influência das grandes estruturas regionais, a exemplo do Arco de Ponta Grossa. O aprofundamento dos conhecimentos sobre este aqüífero está se dando de forma mais intensa em razão do projeto denominado "Proteção Ambiental e Gerenciamento Sustentável Integrado do Sistema Aqüífero Guarani", que tem como participantes os governos do Brasil, Uruguai, Paraguai e Argentina, assim como do BIRD/GEF e da OEA.

\section{OBJETIVOS}

Com base em dados geológicos e aerogeofísicos, pretende-se mostrar que 0 Arco de Ponta Grossa compartimenta o aqüífero no território paranaense. Esta compartimentação faz com que o movimento de fluxo das águas subterrâneas e a sua qualidade, tornem-se diferenciadas em relação a outras regiões como no Estado de
São Paulo. É um estudo de caso com evidências marcantes e que por esta razão pode ocorrer também em outras grandes estruturas, como no Arco do Rio Grande, no Arco de Assunção e no Arco de Campo Grande. Outro aspecto interessante, como objetivo deste trabalho, é mostrar que as áreas de descarga estão intimamente relacionadas com estruturas tectônicas, e que é através delas que a água ascende para a superfície recarregando a Formação Serra Geral, assim como desaguando nas grandes drenagens, a exemplo do rio Iguaçu próximo da sua foz.

\section{LOCALIZAÇÃO}

Este sistema aqüífero refere-se ao pacote de rochas arenosas saturadas com água que ocorrem subjacentes ao conjunto de rochas que constitui a Formação Serra Geral. Esta camada, com espessura que varia de 200 a $800 \mathrm{~m}$, distribui-se numa área de aproximadamente $1.195 .000 \mathrm{~km}^{2}$, sendo $213.200 \mathrm{~km}^{2}$ no Estado do Mato Grosso do Sul, $157.600 \mathrm{~km}^{2}$ no Estado do Rio Grande do Sul, $155.800 \mathrm{~km}^{2}$ no Estado de São Paulo, $131.300 \mathrm{~km}^{2}$ no Estado do Paraná, $55.000 \mathrm{~km}^{2}$ no Estado de Goiás, $52.300 \mathrm{~km}^{2}$ no Estado de Minas Gerais, $49.200 \mathrm{~km}^{2}$ no Estado de Santa Catarina e $26.400 \mathrm{~km} 2$ no Estado do Mato Grosso. No Paraguai o aquífero ocupa uma área de $71.700 \mathrm{~km}^{2}$, na Argentina $225.500 \mathrm{~km}^{2}$ e no Uruguai 58.500 $\mathrm{km}^{2}$ (Araújo et al. 1995). Em quase toda a sua extensão, este sistema aqüífero encontra-se sotoposto por rochas basálticas cuja espessura máxima ultrapassa 1.000 metros (Figura 1). 


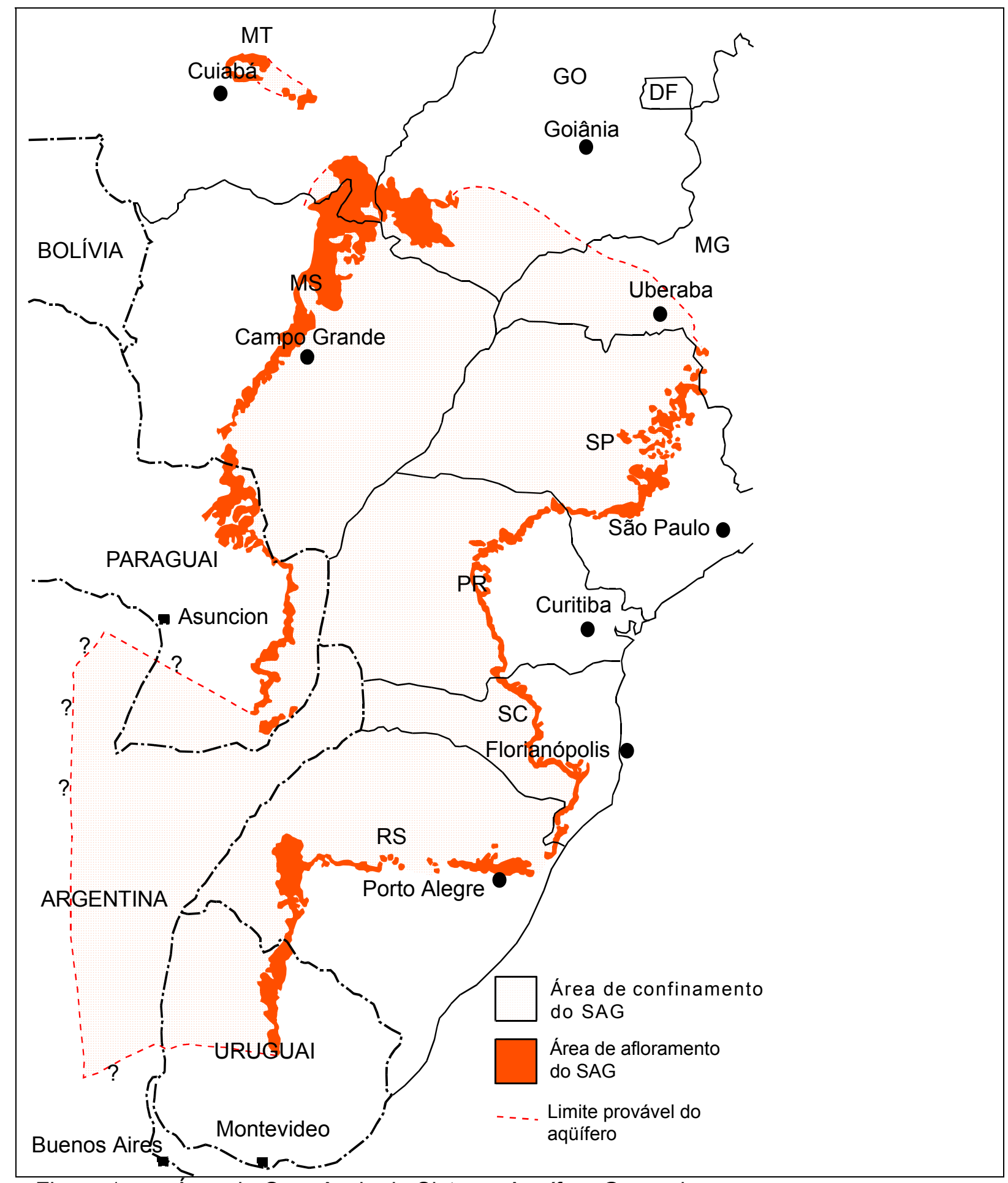

Figura 1 - Área de Ocorrência do Sistema Aqüífero Guarani

CARACTERIZAÇÃO HIDROGEOLÓGICA O termo "Sistema Aqüífero Guarani", é apresentado como uma proposta para homenagear a memória da nação Guarani, e para unificar uma terminologia relativa aos estratos do Triássico (Formações Pirambóia e Rosário do Sul, no Brasil, e Buena Vista, no Uruguai) e do Jurássico (Formações Botucatu, no Brasil, Misiones no Paraguai e Tacuarembó no Uruguai e na Argentina), sob o ponto de vista hidrogeológico. Considerado como um dos maiores reservatórios subterrâneos do mundo, a explotação da água através de poços profundos permite a extração por unidade de captação de até $780.000 \mathrm{l} / \mathrm{h}$, surgente, a exemplo do poço perfurado em Ibiporã, no Estado do Paraná-Brasil. Em várias regiões do sul e do sudeste do Brasil, assim como na Argentina e Uruguai, existe o fenômeno 
da surgência natural, inclusive com a temperatura da água atingindo $65^{\circ} \mathrm{C}$.

A primeira base técnico-científica sobre o SAG, no âmbito da Bacia Geológica do Paraná, foi elaborada por Araújo et al., (1995). Este documento, que inclui um arcabouço hidrogeológico na escala 1:5.000.000, é composto de mapas de isópacas do aquífero, estrutural do topo do aqüífero, isópacas de rochas acima do aqüífero, cotas potenciométricas e um mapa de isotermas. Para a elaboração dos mesmos, foram utilizados 333 poços, sendo a maioria perfurados à prospecção de petróleo. Os dados disponíveis atualmente ultrapassam 500 poços, incluindo aqueles utilizados por Araújo et al. (1995; Figura 2). Além destes, o banco de dados é muito extenso e ainda deverão ser inventariados cerca de 20.000 poços nas bacias do Paraná e Chaco-Paraná, dos quais, aproximadamente $10 \%$, são poços para exploração do SAG.

Os arenitos reservatório do SAG são confinados pelas rochas vulcânicas da Formação Serra Geral e por rochas sedimentares triássicas e jurássicas de baixa permeabilidade. Os arenitos do Jurássico, de origem eólica, constituem-se nos melhores reservatórios em praticamente toda a Bacia, com porosidade média de $17 \%$ e condutividade hidráulica da ordem de 0,2 a $4,6 \mathrm{~m} / \mathrm{dia}$, com boa maturidade textural e composicional. Os reservatórios triássicos, de origem flúvio-lacustre/eólico, são afetados por altos níveis de argilosidade, que comprometem sua eficiência hidráulica, com porosidade média de $16 \%$ e condutividade hidráulica inferior a 0,01 até 4,6 m/dia (Araújo et al., 1995).

O volume total de água no SAG pode ser estimado com base nos seguintes dados:
- espessura média de 228 m (considerando os poços que atravessaram topo e base da Formação Botucatu);

- distribuição em área de $840 \mathrm{mil} \mathrm{km}^{2}$ no Brasil, $225 \mathrm{mil} \mathrm{km}^{2}$ na Argentina, $72 \mathrm{mil}$ $\mathrm{km}^{2}$ no Paraguai e 58 mil km ${ }^{2}$ no Uruguai, totalizando uma área de 1.195 milhões $\mathrm{km}^{2}$;

- porosidade efetiva média de $17 \%$;

- que totalizam: $228 \times 1.195 \times 10^{6} \times 0,17 \approx$ $46.280 \mathrm{~km}^{3}$.

Tais dados são suficientes para afirmar que o SAG é um sistema hidrogeológico com capacidade volumétrica expressiva, taxas de recarga e tempo de renovação que possibilitam poços com vazões da ordem de $800.000 \mathrm{~m}^{3} / \mathrm{h}$, mas que apresenta particularidades quanto ao balanço hídrico e comportamento hidráulico que refletem as heterogeneidades das bacias do Paraná e Chaco-Paraná. O gerenciamento destes recursos deve, portanto, considerar sistemas de fluxo em diversas ordens hierárquicas, considerando a movimentação de água na escala do próprio sistema aqüífero, como também em escalas intermediárias ou locais. As principais surgências naturais do aqüífero estão localizadas em áreas com cotas inferiores a $400 \mathrm{~m}$, predominantemente margeando as principais drenagens da região, a exemplo dos rios Paraná, Paranapanema, Iraí, Piquiri, Iguaçu e Uruguai (Figura 3). É exatamente nestas regiões que estão localizadas as principais estâncias que utilizam fontes naturais do SAG, cujas alcançam na superfície, temperaturas de até $43{ }^{\circ} \mathrm{C}$, devido às propriedades geotermais do aqüífero. $\mathrm{O}$ confinamento do aqüífero impõe condições de artesianismo a partir de algumas dezenas de quilômetros de distância das áreas de afloramento. 
Rev. Águas Subterrâneas nº 17/ Maio 2003.

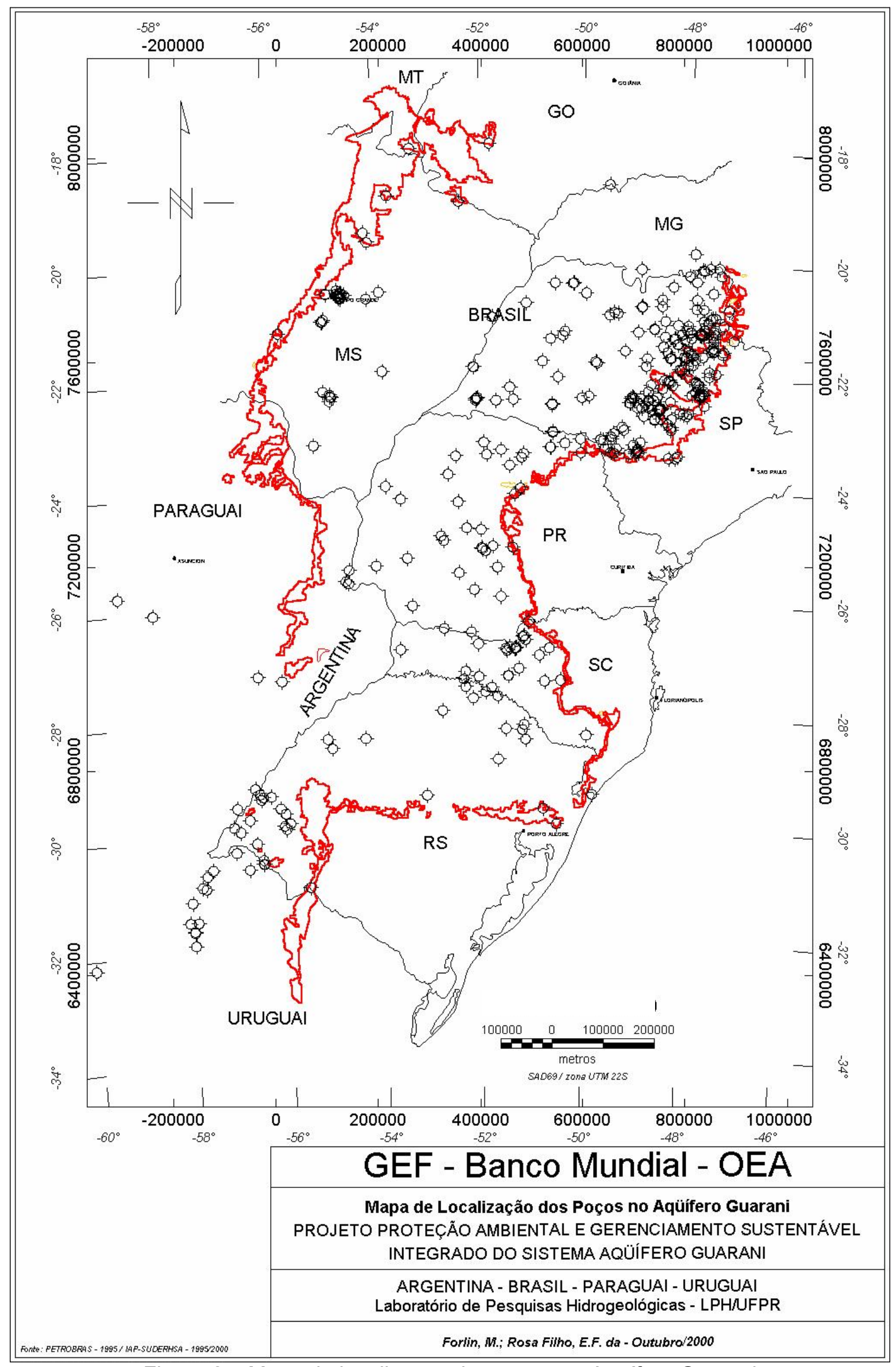

Figura 2 - Mapa de localização dos poços no Aqüifero Guarani 
Embora as informações existentes possibilitem uma visão global sobre a distribuição espacial do aqüífero em toda a região de sua ocorrência, os dados não são suficientes para uma caracterização conclusiva em termos de espessuras e sobre as áreas de afloramento. No período compreendido entre a elaboração dos mapas pré-existentes e os dias atuais, várias perfurações foram executadas e esses dados ainda não foram suficientemente tratados. Além disto, uma das grandes dúvidas a respeito dos dados existentes refere-se à localização dos poços, o que exige, em alguns casos, o levantamento das coordenadas geográficas, assim como sobre a qualidade da água dos poços. Recomenda-se, por esta razão, uma revisão sobre a localização dos poços, determinando-se a posição do nível da água de alguns poços, de seu posicionamento e altitude, assim como a coleta de amostras para análises físico-químicas e isotópicas. Estes dados permitirão avaliar áreas de recarga/descarga, regiões de grandes afloramentos e concentração de poços (superbombeamento), e desta forma subidiarão as medidas de proteção e de gerenciamento sustentável do aqüífero.

\section{CONTEXTO GEOLÓGICO- ESTRATIGRÁFICO}

As peculiaridades quanto ao comportamento hidrológico e qualidade da água do SAG refletem os fatores sedimentares, litológicos e tectônicos inerentes às bacias do Paraná e Chaco-Paraná. Atualmente o conhecimento disponível sobre essas bacias advém de mapeamentos básicos ou estudos exploratórios para petróleo que, embora apresentem outro direcionamento de objetivos, geram dados que podem ser diretamente aplicáveis à extração e proteção da água subterrânea. Dentre os vários resultados disponíveis na literatura, destacase o Mapa de Integração Geológica da Bacia do Prata e Áreas Adjacentes (Schobbenhaus e Lopes 1998), onde é apresentada uma proposta de correlação estratigráfica da Região Extra-Andina, para fins de mapeamento geológico 1:2.500.000. Essa base de dados deve servir de ponto de partida para levantamentos localizados e compilação de mapas de caráter local. Para o SAG, a interação sistêmica entre múltiplas variáveis nessas bacias exige duas vertentes de análise, quais sejam: (a) estudo 96 dos aspectos geológicos relacionados à distribuição de vazões e compartimentação hierárquica/geométrica do sistema e (b) aspectos referentes às concentrações normais ou anômalas de elementos químicos e potabilidade.

$\mathrm{Na}$ primeira vertente, vale mencionar a relação entre a geodinâmica (termomecânica) das bacias do Paraná e ChacoParaná, com as características intrínsecas dos recursos hídricos existentes, onde fatores hidrogeológicos refletem a história paleodeposicional das bacias, principalmente para as rochas triássicas e jurássicas, e as atividades tectônicas formadoras de grandes alinhamentos ou enxames de diques de diabásio. A segunda vertente compreende a interação águarocha e as comunicações através de condutos regionais, que controlam a qualidade de água no SAG.

Assim sendo, a análise geológica das bacias do Paraná e Chaco-Paraná é uma etapa indispensável para o acréscimo de conhecimento que se faz necessário para subsidiar as ações de gerenciamento para uso e proteção do SAG. Tal análise é dependente de levantamentos básicos em escala de detalhe e semi-detalhe, incluindo novos levantamentos de campo e reavaliação de poços, seções sísmicas e mapas existentes, neste caso com objetivo hidrogeológico e não simplesmente acadêmico-científico ou voltado à indústria do petróleo. Com essa linha de raciocínio, a seguir é apresentado sinteticamente o estado da arte do conhecimento básico das bacias do Paraná e Chaco-Paraná, de tal forma a alavancar o desenvolvimento do plano de ações.

O Sistema Aqüífero Guarani abrange quase toda a área das Bacias Sedimentares do Paraná e Chaco-Paraná. As rochasreservatório do SAG são os arenitos das Formações Pirambóia, Rosário do Sul e Botucatu, no Brasil, Misiones no Paraguai e Tacuarembó no Uruguai e Argentina.

Tendo em vista a localização da superfície potenciométrica acima do topo dos reservatórios sedimentares (Figura 4), as rochas vulcânicas da Formação Serra Geral funcionam também como reservatórios, além de seu caráter de barreira hidráulica. Dessa forma, pelo menos parcialmente, os aqüíferos fraturados nos basaltos devem ser considerados como componentes do mesmo sistema 
hidrogeológico, consoante à provável de similaridade quanto a alguns padrões de conexão com o aqüífero granular e o caráter fluxo.

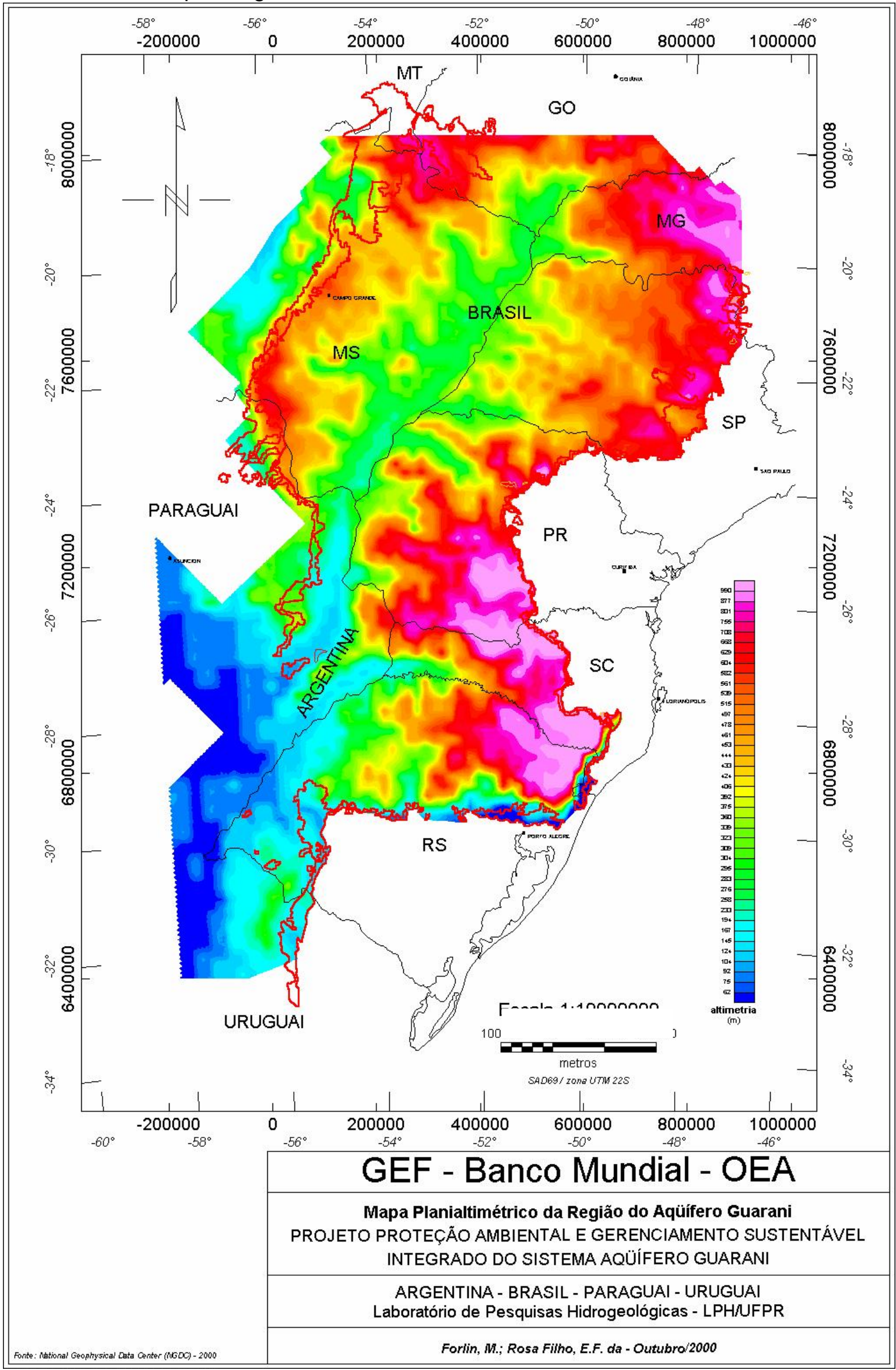

Figura 3 - Mapa planialtimétrico da região do Aqüífero Guarani. 




Figura 4 - Seção geológica NS da Bacia do Paraná representando o Sistema Aqüífero Guarani, com indicação das Formações Pirambóia, Botucatu e Serra Geral. Notar a localização da superfície potenciométrica sempre acima do topo da Formação Botucatu e as regiões com artesianismo (Araújo et al. 1995).

A Bacia do Paraná é uma das 15 bacias sedimentares terrestres que ocorrem no território brasileiro, sendo representada por uma depressão alongada segundo a direção NS, no centro-sul do Brasil, que se estende ao Paraguai, Uruguai e Argentina, com área de aproximadamente $1.600 .000 \mathrm{~km}^{2}$. A Bacia do Paraná é classificada como uma bacia intracratônica, por ter sua evolução totalmente sobre área cratônica. O termo cráton é aqui utilizado para caracterizar uma parte da crosta terrestre, desenvolvida sobre placa continental relativamente pouco deformada, em comparação às faixas onde ocorre a formação de montanhas. Segundo Milani \& Thomaz Filho (2000), as seqüências cratônicas do Fanerozóico formaram-se desde o início do Ordoviciano até o Cretáceo, ocupando mais de 3,5 milhões de $\mathrm{km}^{2}$, distribuídos em 5 grandes bacias sedimentares: Solimões, Amazonas, Parnaíba e Paraná no Brasil, e ChacoParaná na Argentina, Paraguai e Uruguai. Segundo Soares et al. (1978), uma característica peculiar dessas bacias intracratônicas é a evolução policíclica, em longos períodos de tempo, com fases sucessivas de subsidência e acumulação de grandes seqüências deposicionais, separadas por discordâncias regionais que refletem épocas de soerguimento e erosão.

As rochas sedimentares da Bacia do Paraná e Chaco-Paraná estão distribuídas em várias unidades litoestratigráficas (Figuras 5 e 6), totalizando 6.000 metros de espessura. $O$ registro tectono-estratigráfico conhecido evidencia a interação de fenômenos orogênicos nas bordas da placa sul-americana, com eventos epirogênicos marcados por épocas de subsidência, soerguimento e magmatismo, no interior da placa. As rochas da bacia são principalmente terrígenas, constituindo unidades depositadas durante todo 0 Paleozóico e Mesozóico, com contribuições localizadas de rochas carbonáticas durante - Permiano. As unidades maiores já receberam status de sequências conforme o conceito de Sloss (1963; in Soares et al. 1978, Soares 1992), grupos e formações (Milani et al. 1994) e sequências conforme o conceito de Vail et al. (1977; in Milani \& Ramos, 1998). As seis maiores seqüências são as que seguem (mod. Soares, 1992 e Milani \& Ramos, 1998): ordovício-siluriana, devoniana, pensilvaniana-permiana, triássica, jurássico-eocretácea e neocretácea.

\section{ASPECTOS LITOESTRATIGRÁFICOS DO SISTEMA AQÜÍFERO GUARANI}

As Formações Pirambóia e Rosário do Sul, no Brasil, e Buena Vista, no Uruguai, são unidades correlatas e pertencentes à seqüência triássica; as Formações Botucatu, no Brasil, Misiones, no Paraguai, e Tacuarembó, no Uruguai e Argentina, assim como a Formação Serra Geral, compõem a seqüência jurássico-eocretácea. A Formação Misiones aflora ao longo da borda oeste da Bacia do Paraná (Figura 5) e apresenta uma área de exposição de aproximadamente $36.000 \mathrm{~km}^{2}$, em uma faixa norte-sul com cerca de $500 \mathrm{~km}$ de comprimento e $60 \mathrm{~km}$ de largura. Os sedimentos distribuem-se integralmente na região oriental do Paraguai, bordejando de forma contínua a área de afloramento dos derrames basálticos da Suíte Magmática Alto Paraná ou Serra Geral. A Formação Serra Geral é composta por rochas ígneas vulcânicas, representadas por basaltos 
toleíticos e andesitos basálticos, ocorrendo quantidades subordinadas de riolitos e riodacitos (Milani, 1997). Diabásios intrusivos em toda a seção sedimentar da Bacia, na forma de soleiras e diques, são também correlacionados à Formação Serra Geral. As formações Pirambóia e correlatas representam a deposição fluvial em época de continentalização da Bacia do Paraná, no
eo-Triássico, com a formação subseqüente de uma discordância associada a uma fase de erosão pronunciada entre o Triássico e o Jurássico. Um novo período de acumulação iniciou com a deposição dos arenitos eólicos da Formação Botucatu e correlatas, sobrepostos pelas rochas vulcânicas da Formação Serra Geral.

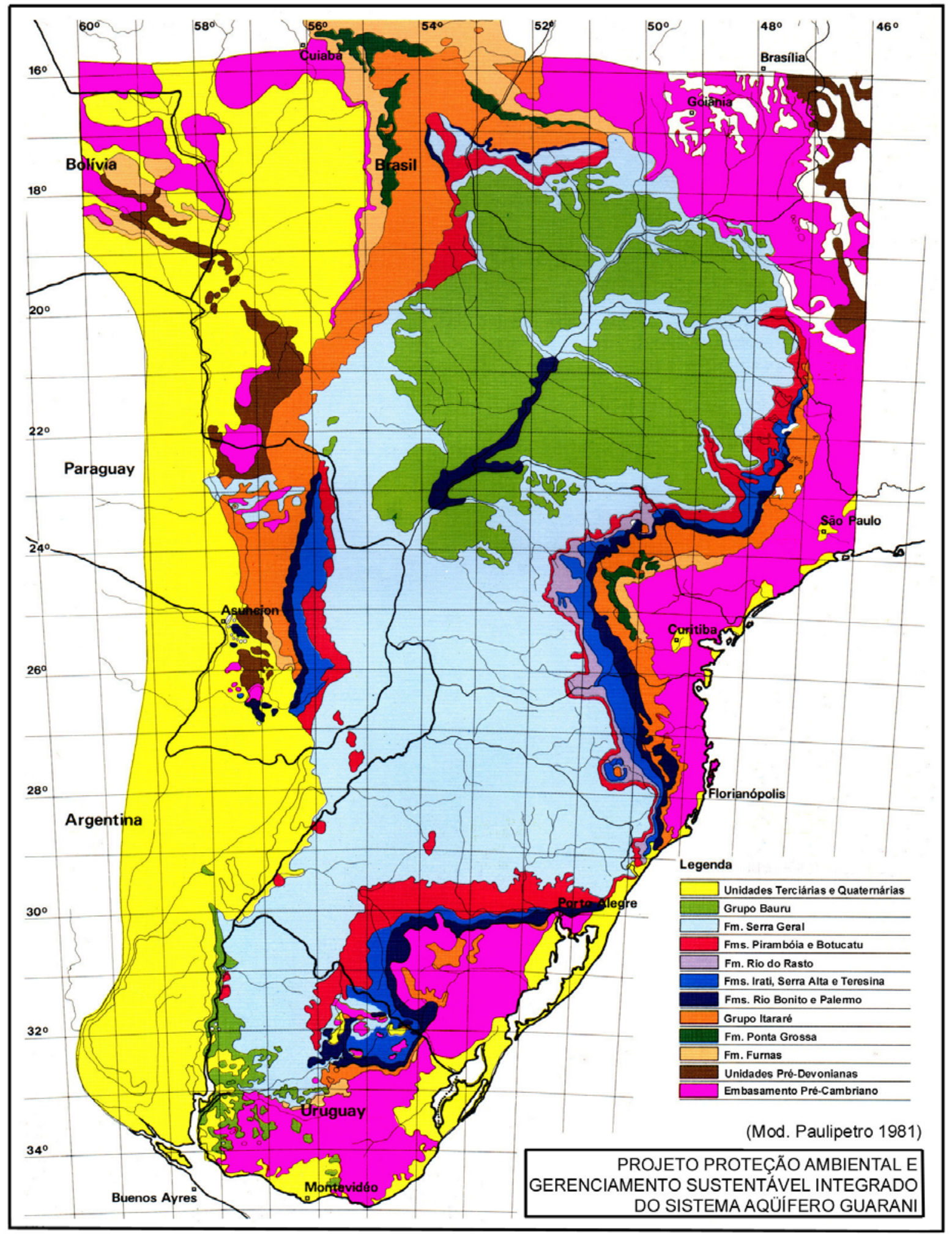

Figura 5 - Mapa geológico simplificado da Bacia do Paraná (mod. Paulipetro, 1981). 


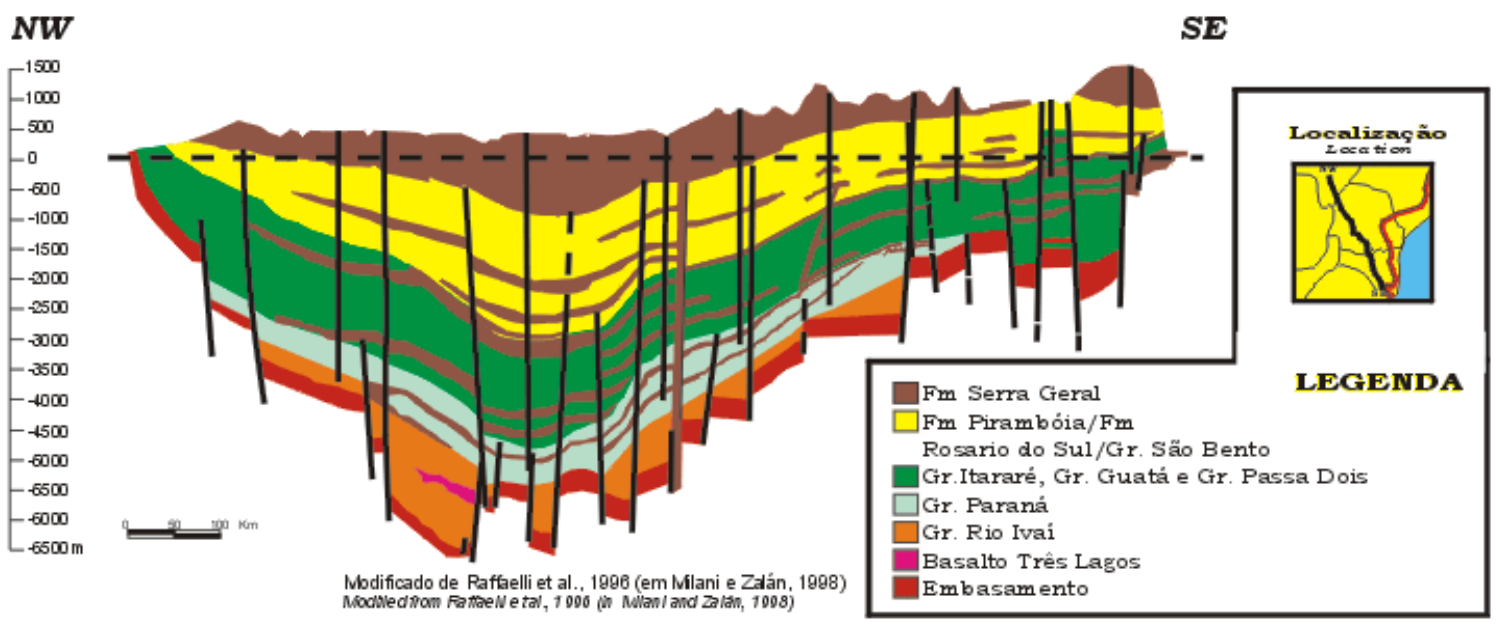

Figura 6 - Seção geológica regional da Bacia do Paraná (mod. Paulipetro, 1981).

Como já referido, o SAG compreende várias unidades sedimentares correlatas, aflorantes no Brasil, Uruguai, Argentina e Paraguai. Neste trabalho são apresentados detalhadamente os aspectos litoestratigráficos das Formações Pirambóia e Botucatu, em virtude de sua maior extensão aflorante no SAG e por apresentarem características litológicas e estratigráficas representativas das unidades correlatas. De acordo com Milani et al. (1994), as formações Pirambóia e Rosário do Sul são constituídas por arenitos avermelhados a esbranquiçados, localmente conglomeráticos, depositados em sistemas continentais flúvio-lacustres/eólicos. As formações Botucatu e Tacuarembó são representadas por arenitos avermelhados bem selecionados, com estratificações cruzadas de grande porte, depositados em sistemas eólicos, relacionados à formação de um extenso campo de dunas. As diferenças litológicas podem ser visualizadas nos perfis de poços que atravessam tais formações na Bacia do Paraná, onde são evidentes as características de granulometria mais grossa, maior porosidade e homogeneidade textural/litológica dos arenitos Botucatu, em contraposição aos litotipos da Formação Pirambóia, que apresentam ampla variedade textural e menor porosidade média, evidenciada pelos perfis petrofísicos. Segundo Rebouças (1976), os sedimentos flúvio-lacustres (triássicos) têm granulometria fina, com diâmetro médio de $0,12 \mathrm{~mm}$ e teores de argila superiores a
$20 \%$, enquanto os sedimentos eólicos (jurássicos) são formados por grãos de quartzo bem arredondados, com diâmetro médio dos grãos de $0,18 \mathrm{~mm}$ e teor de argila inferior a $10 \%$.

\section{Formação Pirambóia}

O termo Pirambóia foi proposto originalmente por Pacheco em 1927, como "grez Pirambóia", que constituía o membro inferior do Triássico no Estado de São Paulo (Mezzalira 1981). Até a década de 1970, a Formação Pirambóia recebeu designações como fácies, litótopo ou simplesmente Arenito Pirambóia (e.g. Paraguassu 1968) sendo considerada como a parte inferior da Formação Botucatu. Embora propostas para divisão formal entre as duas formações tenham sido apresentadas em vários trabalhos (e.g. Soares 1975) persistem, ainda hoje, dúvidas entre o limite e diferenças entre estas unidades.

Este limite superior entre as formações Pirambóia e Botucatu nem sempre é preciso, sendo que a distinção se faz pela diversidade litológica e faciológica entre elas, onde localmente ocorre discordância marcada por camada conglomerática (Caetano-Chang \& Wu 1992; vide Figura 7). O contato basal com o Grupo Passa Dois foi reconhecido como transicional nas porções mais centrais da bacia, porém nas partes de borda da bacia é marcado por uma camada areno-argilosa com seixos de sílex, denominada no Estado de São Paulo como Camada Porangaba (Matos 1995, apud Matos \& Coimbra 1997). 


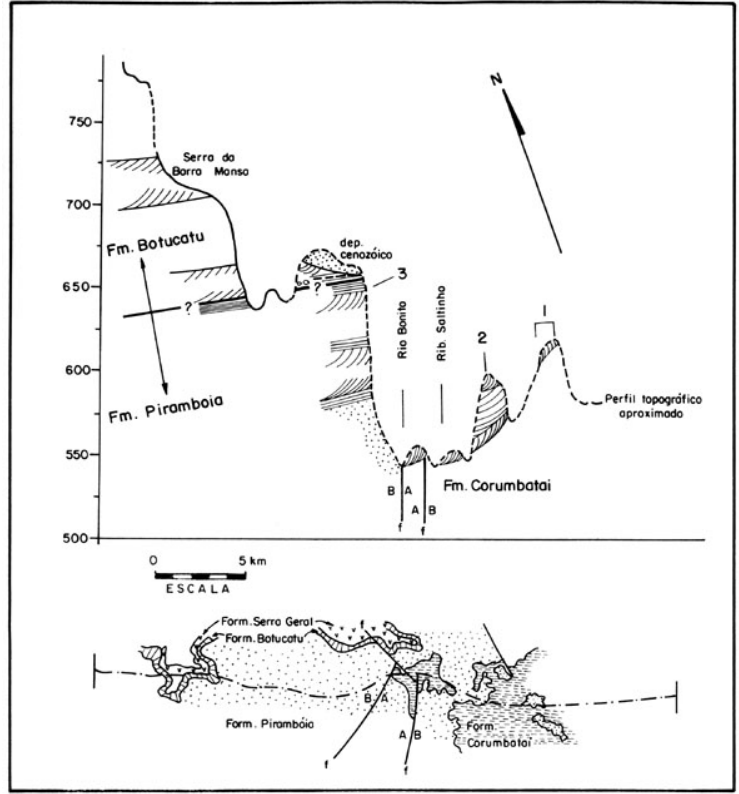

Figura 7 - Perfil geológico em trecho da Rodovia Castelo Branco, SP (mod. Soares 1973; apud Caetano-Chang \& Wu 1992).

Litologicamente, a Formação Pirambóia é constituída por arenitos esbranquiçados, amarelados ou avermelhados, de granulometria média a muito fina, siltoargilosos, com grãos sub-angulososa e subarredondados. Apresenta intercalações de argilitos, siltitos e localmente porções conglomeráticas com seixos de argila (Schneider et al. 1974). Os arenitos são de seleção variável, predominando aqueles bem a regularmente selecionados, com pequeno conteúdo em silte, que constituem a matriz dos arenitos, ou intercalam-se a estes na forma de lâminas nas estratificações cruzadas. Como estruturas sedimentares predominantes ocorrem estratificações cruzadas, acanaladas ou tabulares, tangenciais de base, geralmente de grande porte. Lamitos ocorrem subordinadamente (Caetano-Chang \& Wu 1992).

Caetano-Chang \& Wu (1992) propõem uma sucessão de sub-ambientes para a Formação Pirambóia, em geral de origem eólica, com o inter-relacionamento vertical e lateral de associação de fácies de dunas, de interdunas úmidas e aquosas, de sandsheets, cortadas por canais fluviais temporários. Dentro deste contexto a fácies de estratificações cruzadas de médio a grande porte, interpretadas por Soares (1975) como depósitos de canal fluvial meandrante, intercalados a depósitos tabulares com estratificação plano-paralela, constituiriam, dentro desta nova visão, uma associação de depósitos de dunas e interdunas eólicas (Caetano-Chang \& Wu 1992). Outros fatores apontados como indicadores de um predomínio eólico para a Formação Pirambóia são: (a) a presença do mineral estaurolita, instável em condições fluviais, tanto na Formação Pirambóia como na Formação Botucatu; (b) a inconsistência da afirmação de que o maior conteúdo de lama na Formação Pirambóia, em relação a Formação Botucatu, seria indicador de ambiente fluvial para a primeira (CaetanoChang \& Wu 1992, Wu \& Caetano-Chang 1992).

O conteúdo fossilífero da Formação Pirambóia é composto de conchostráceos, ostracódeos e restos vegetais. Admite-se idade neotriássica a esta formação pelas relações estratigráficas com as formações Botucatu e Corumbataí e pela correlação com a Formação Rosário do Sul (Schneider et al. 1974, Milani et al. 1994).

\section{Formação Botucatu}

A Formação Botucatu representa um extenso campo de dunas implantado no Jurássico sobre o Gondwana e que foi recoberta no Eocretáceo pelo mais volumoso episódio de vulcanismo intracontinental do planeta registrado pela Formação Serra Geral. O termo "Botucatu" foi originalmente definido por Campos (1899, apud Mezzalira 1981) para designar o "grez molle, vermelho, que em geral na sua parte superior alterna com os augito-porphyritos".

A Formação Botucatu apresenta constituição relativamente monótona de arenitos quartzosos avermelhados, finos a médios, friáveis, com seleção boa a regular e pouca matriz. Os grãos são foscos e geralmente arredondados e normalmente apresentam bimodalidade. Ocorrem intercalações de arenitos argilosos, mal selecionados e, localmente, na porção basal da unidade uma camada de arenito grosso a conglomerático pode estar presente.

As estruturas sedimentares mais típicas são as estratificações cruzadas tangenciais em grandes cunhas, que para o topo, passam a estratificação plano-paralela e cruzada acanalada. Zonas silicificadas também são comuns nos arenitos da Formação Botucatu principalmente na porção superior próximo ao contato com as 
vulcânicas da Formação Serra Geral (Paragassu 1968).

O contato inferior é discordante com - embasamento e com formações paleozóicas. Com a Formação Pirambóia o contato tem sido considerado concordante, mas localmente esta relação pode ser discordante. A Formação Serra Geral encontra-se em discordância sobre os arenitos da Formação Botucatu (Schneider et al. 1974), ocorrendo também na forma de diques e sills, principalmente em sua porção superior (Figura 8).

Os depósitos da Formação Botucatu constituem o registro de deposição eólica em condições desérticas com predomínio de extensos ergs associados e sub-ambientes desérticos como indicado por depósitos de wadis (Soares 1975, Schneider et al. 1974, Caetano-Chang \& Wu 1992).



Figura 8 - Perfil geológico na Rodovia Marechal Rondon, SP (mod. Soares 1973; apud Caetano-Chang \& Wu 1992).

\section{ASPECTOS ESTRUTURAIS DO SISTEMA AQÜÍFERO GUARANI}

O Sistema Aqüífero Guarani apresenta vários condicionantes estruturais, destacando-se: os depocentros da Formação Serra Geral, a ativação de sistemas de falhas, os soerguimentos nas bordas e a ativação dos arcos de Rio
Grande e Ponta Grossa (Araújo et al. 1995). Com respeito ao controle exercido pelos arqueamentos, vale ressaltar a existência de enxames de diques de diabásio, com direção predominante NW, que ocorrem ao longo do Arco de Ponta Grossa (Ferreira 1982a,b). A presença dos diques exerce um papel fundamental na compartimentação estrutural do SAG, formando três grandes compartimentos: (1) a norte do Arco de Ponta Grossa, (2) entre os arcos de Ponta Grossa e Rio Grande e (3) a sul do Arco de Rio Grande, este último coincidente com a Bacia do Chaco-Paraná. Segundo Araújo et al. (1995), os regimes hidrológicos são distintos entre os três compartimentos, levando a uma segmentação no padrão de fluxo a partir das zonas de recarga nas bordas norte e nordeste da Bacia, com descarga principal a sudoeste, onde ocorrem as áreas pantanosas das bacias hidrográficas dos rios Uruguai e Paraná. O gradiente de fluxo regional é modificado por descargas locais induzidas pelo cruzamento de falhas regionais e enxames de diques. A contaminação do aqüífero fraturado pela água do aqüífero arenoso já foi evidenciada em trabalhos anteriores (Rosa Filho et al., 1999 inédito; Figura 9). Entender essa contaminação e posicionar as zonas intermediárias de descarga, consistem em aspectos exploratórios extremamente importantes, principalmente para o território brasileiro.

No Estado do Paraná, os rios Ivaí, Piquiri e Iguaçu estão instalados sobre grandes alinhamentos estruturais denominados, respectivamente, de: Alinhamento do Rio Alonzo, Alinhamento do Rio Piquiri (Ferreira, 1982a,b) e Alinhamento do Rio Iguaçu. Além destes três alinhamentos ocorrem, a norte do Rio Ivaí, o Alinhamento São Jerônimo-Curiúva e o Alinhamento Guapiara, este último compreendendo o limite norte do Arco de Ponta Grossa (Ferreira et al., 1981). Estas feições indicam o forte condicionamento estrutural da região oriundo dos vários episódios tectônicos de reativações de antigas estruturas do embasamento, em especial as com direções NW, que passam a afetar toda a seqüência vulcanosedimentar da Bacia do Paraná e que influenciaram $\mathrm{o}$ armadilhamento $\mathrm{e}$, sobremaneira, a modificação tectônica de reservatórios para água subterrânea. Indícios de neotectônica também são 
descritos para a região e serão alvos de levantamentos visando a caracterização do campo de esforços atuantes na região, importante para o planejamento da exploração do SAG.

A compartimentação da Bacia do Paraná em blocos tectônicos separados por falhas é refletida também na compartimentação do SAG. Em caráter preliminar, são apresentadas superfícies potenciométricas geradas por krigagem (Figura 10), que consideram hipoteticamente a segmentação do SAG pelas falhas NW. A observação de dois setores específicos, a nordeste e a sudoeste do Arco de Ponta Grossa, sugere a influência dos enxames de diques de diabásio na potenciometria. As figuras não demonstram um efeito de interpolação porque os parâmetros iniciais foram os mesmos para os dois mapas. A diferença é que o mapa da figura 10b considera os alinhamentos NW como breaklines, ou seja, interpola separadamente os blocos de um lado e do outro da falha/dique. Qualquer interpolação consiste em suavização, independente do método, portanto considerar as breaklines evita que o processamento reduza a superfície a uma média de valores, principalmente quando os dados originais referem-se a blocos distintos. Dessa forma, o mapa resultante é mais real a uma suposta compartimentação geológica, embora esta seja uma hipótese ainda a ser testada.



Figura 9 - Mapa com a localização de poços nas rochas vulcânicas fraturadas, com características hidroquímicas que indicam contaminação por água do aqüífero arenoso (mod. Rosa Filho et al.,1999 inédito). 


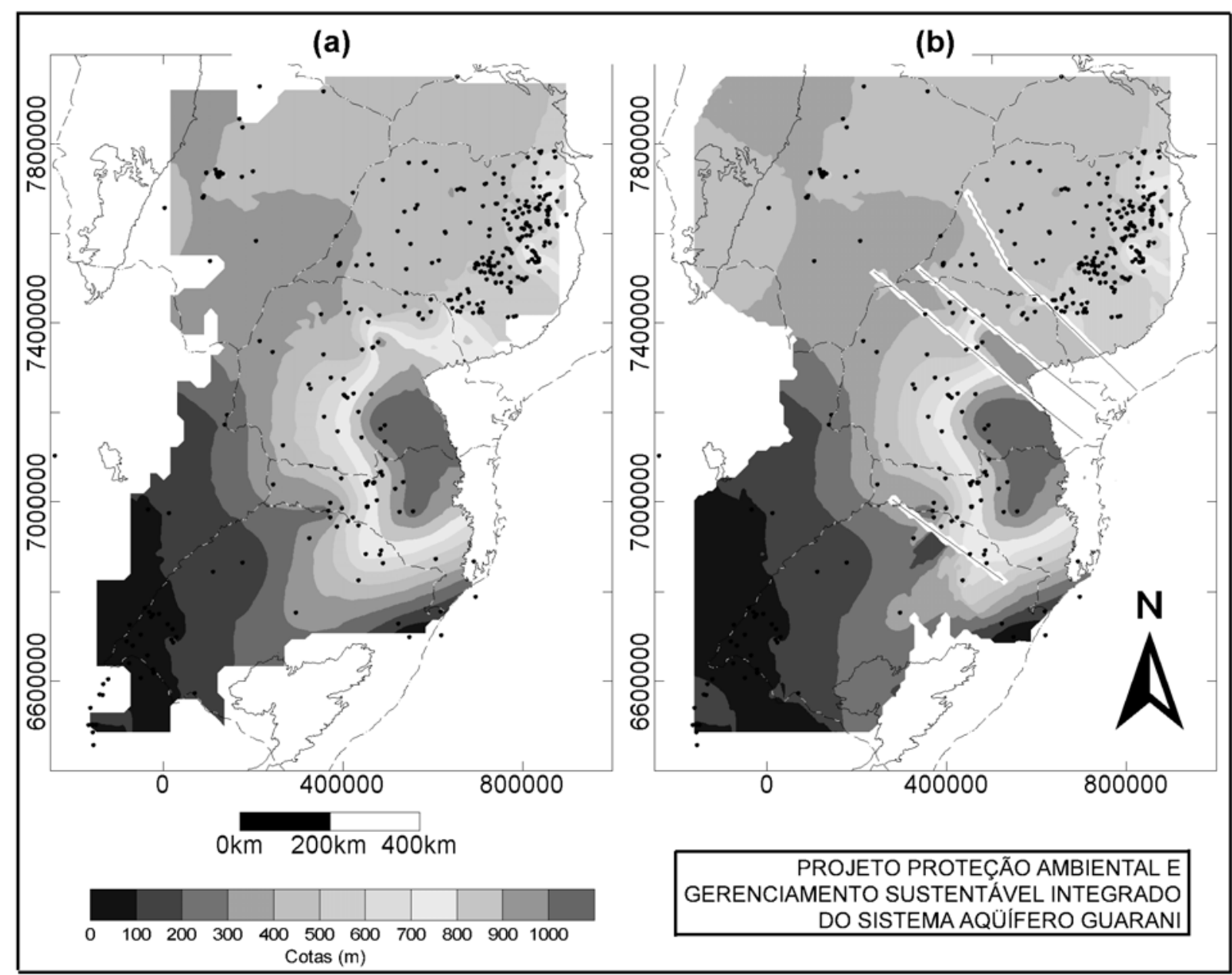

Figura 10 - Mapas potenciométricos das Bacias do Paraná e Chaco-Paraná, gerados a partir da krigagem de dados de poços publicados em Araújo et al. (1995). Notar a diferença entre (a) potenciometria sem considerar a presença das falhas e (b) considerando uma compartimentação hipotética que poderia ser gerada pelas falhas NW, que contêm diques intrudidos. Os pontos representam os poços utilizados e as coordenadas UTM estão referenciadas ao meridiano $51^{\circ}$.

\section{ARCABOUÇO GEOFísICO}

Durante a década de 80 , assistiu-se um grande incremento dos levantamentos aeromagnetométricos na Bacia do Paraná no Brasil, o qual, juntamente com outros estudos geológicos regionais e locais, além de mais de duas dezenas de perfurações profundas para prospecção de hidrocarbonetos, permitiu grandes avanços no conhecimento sobre a origem e a evolução tectônica desta bacia intracratônica. A integração preliminar dos vários projetos listados, realizada por Ferreira (1982a,b), permitiu definir a configuração do Arco de Ponta Grossa, o qual é composto por quatro alinhamentos estruturais-magnéticos, com extensões mínimas de $600 \mathrm{~km}$ e larguras variáveis entre 20 e $100 \mathrm{~km}$, reconhecidos desde a linha de costa até o rio Paraná, reflexo de cerrados enxames de diques de diabásio dispostos segundo a direção NW-SE (Figura 11).

Estudos regionais posteriores realizados pela Petrobrás (Zalán et al. 1990), permitiram avançar na caracterização do arcabouço estrutural-geofísico da Bacia do Paraná. O Laboratório de Pesquisas em Geofísica Aplicada (LPGA/UFPR), possui, atualmente, em seu acervo, cinco aerolevantamentos (Serra do Mar Sul, São Paulo - Rio de Janeiro, Rio Ivaí, Rio Iguaçu e Botucatu), sendo que os dois primeiros recobrem áreas pré-cambrianas do embasamento exposto da bacia. Como pode-se observar nos mapas de contorno do campo magnético residual de parte dos demais projetos, todos na Bacia do Paraná, das Figuras 12, 13 e 14, destaca-se claramente conjuntos de anomalias lineares segundo NW-SE, reflexo de cerrados enxames de diques máficos dispostos 
segundo NW-SE, os quais, certamente, influenciam a circulação das águas subterrâneas. Tais alinhamentos, juntamente com outras estruturas dispostas principalmente segundo a direção NE-SW, foram de fundamental importância no condicionamento e compartimentação de toda a coluna vulcano-sedimentar da bacia, desde o Siluriano até o Cenozóico. Entretanto, a atividade máxima do Arco de Ponta Grossa deu-se no Cretáceo Inferior, por ocasião da ruptura Brasil-África, alojando diques de diabásio e rochas alcalinas (Ferreira \& Algarte, 1979; Ferreira et al. 1981; Ferreira 1982a e b, Almeida 1983) e permitindo o extravasamento de magmas básicos e ácidos, estimado em cerca de $1.500 .000 \mathrm{~km}^{3}$ de lavas, constituindo a Formação Serra Geral. A influência do Arco de Ponta Grossa é facilmente perceptível nos mapas de isópacas e de contorno estrutural das formações Botucatu, Pirambóia, Rosário do Sul, Buena Vista, Misiones e Tacuarembó (Aqüífero Guarani), da Formação Serra Geral e dos pacotes litológicos acima do aqüífero e das isotermas, divulgados por Araújo et al. (1995), recentemente atualizados pelo Laboratório de Pesquisas Hidrogeológicas (LPH/UFPR) e parte integrante do Projeto Proteção Ambiental e Gerenciamento Sustentável do Sistema Aqüífero Guarani. Assim, a proposta de aquisição dos dados digitais dos demais levantamentos e dos dados gravimétricos e de sísmica de reflexão, disponíveis ao público pela Agência Nacional de Petróleo (ANP), será de grande importância para o melhor conhecimento sobre o condicionamento do SAG, em função das relações do aqüífero com a Formação Serra Geral, como também o detalhamento proposto, através de aeromagnetometria e aerogamaespectometria de alta resolução e geofísica terrestre (magnetometria, gamaespectrometria, gravimetria e eletroresistivimetria), possibilitando uma melhor definição das feições geológicas das áreas selecionadas de interesse na área de ocorrência do SAG e suas relações com o condicionamento do aqüífero.

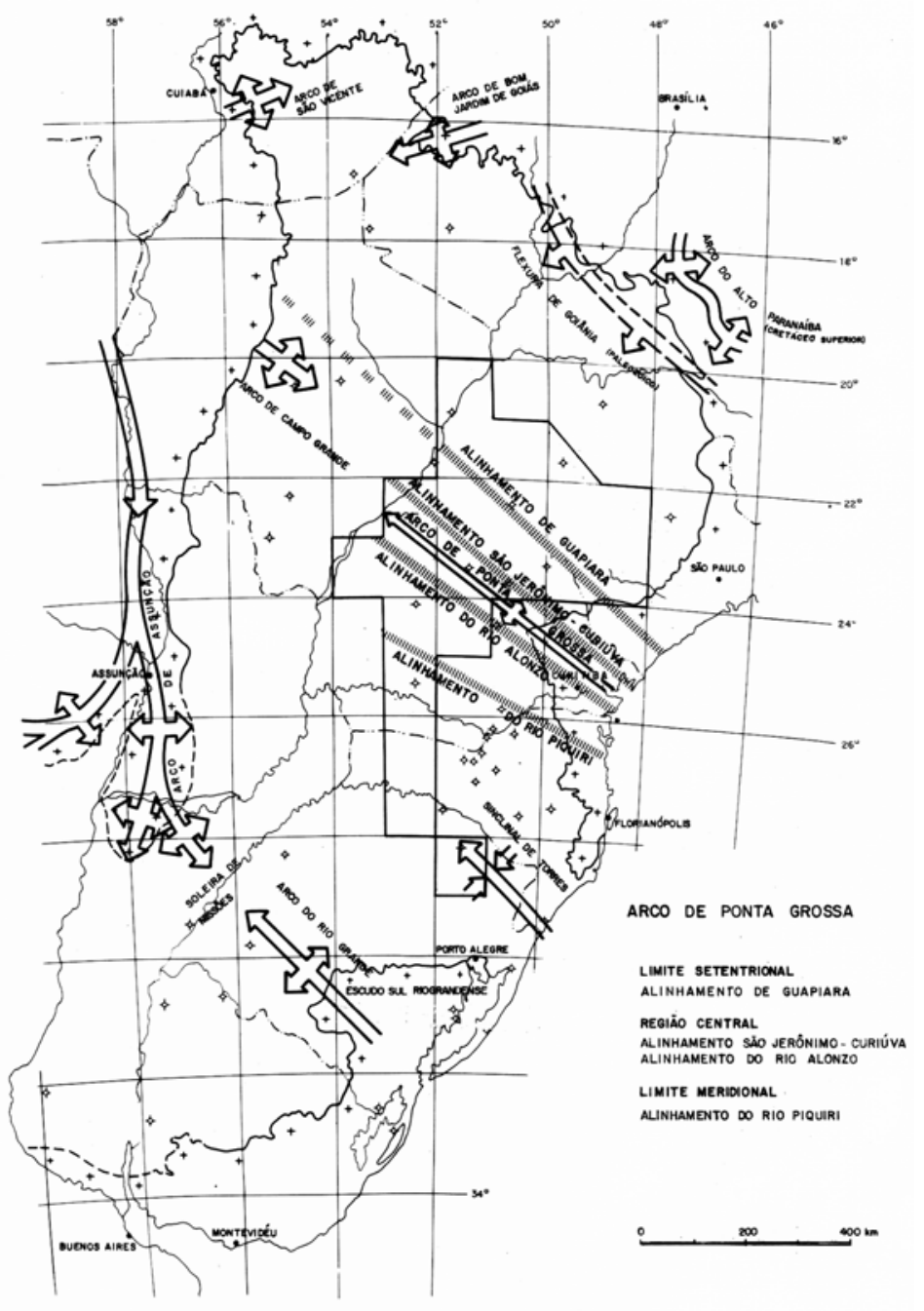


Figura 11 - Configuração do Arco de Ponta Grossa e principais elementos tectônicos da Bacia do Paraná na América do Sul. Fonte: Ferreira (1982a)

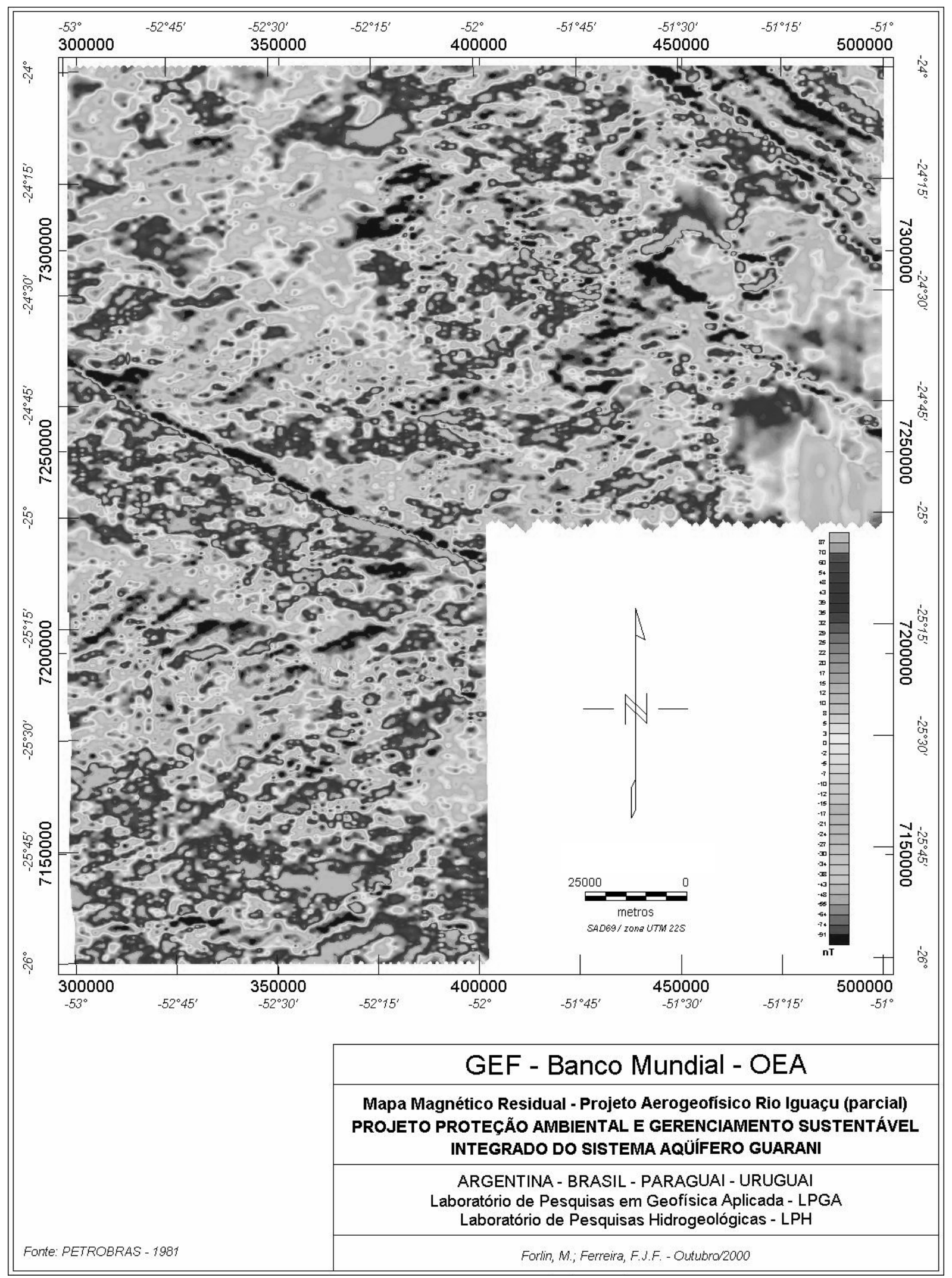

Figura 12 - Mapa Magnético Residual do Projeto Aerogeofísico Rio Iguaçu (parcial) 


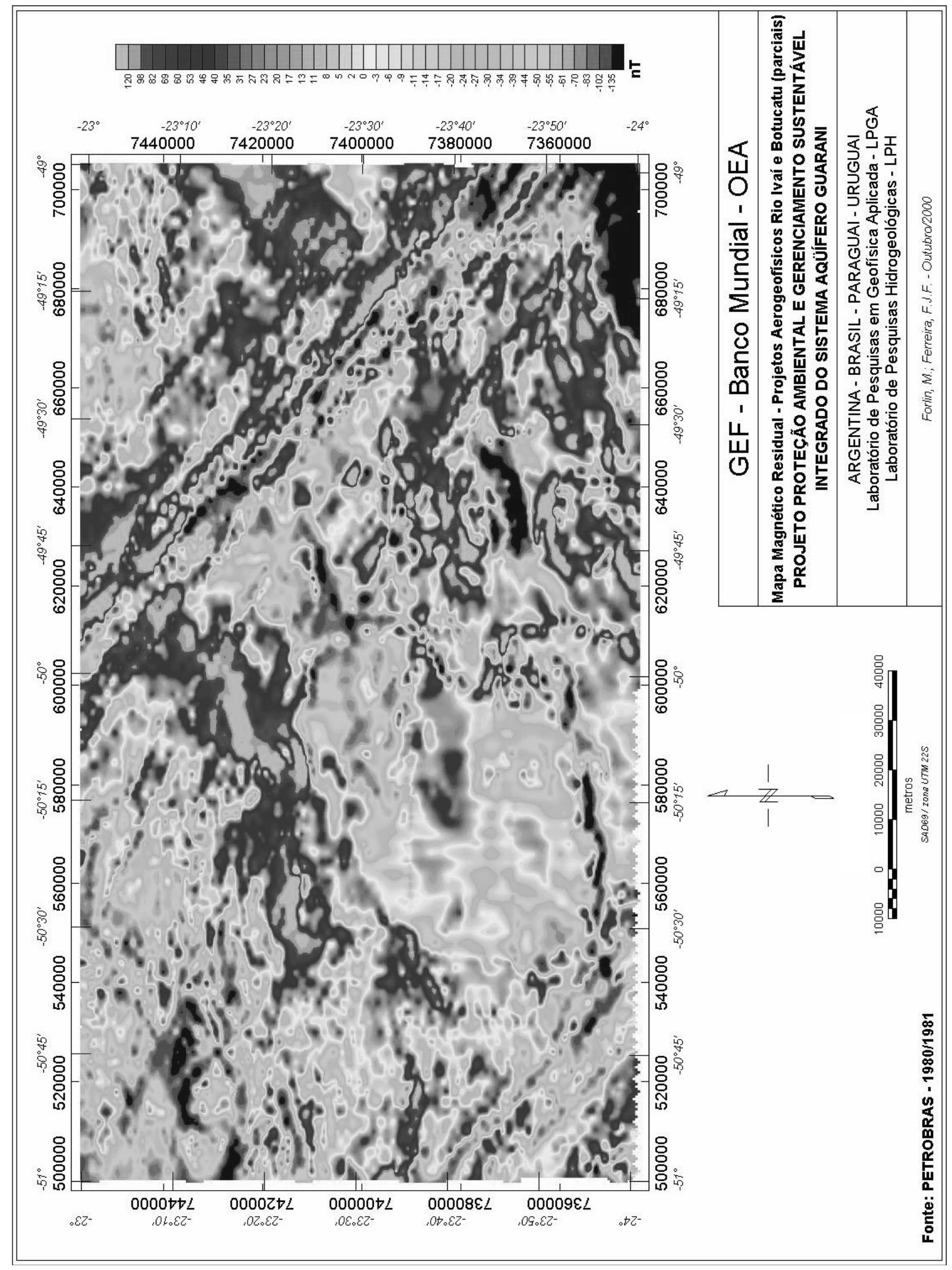

Figura 13 - Mapa Magnético Residual - Projeto Aerogeofísico Rio Ivaí e Botucatu 


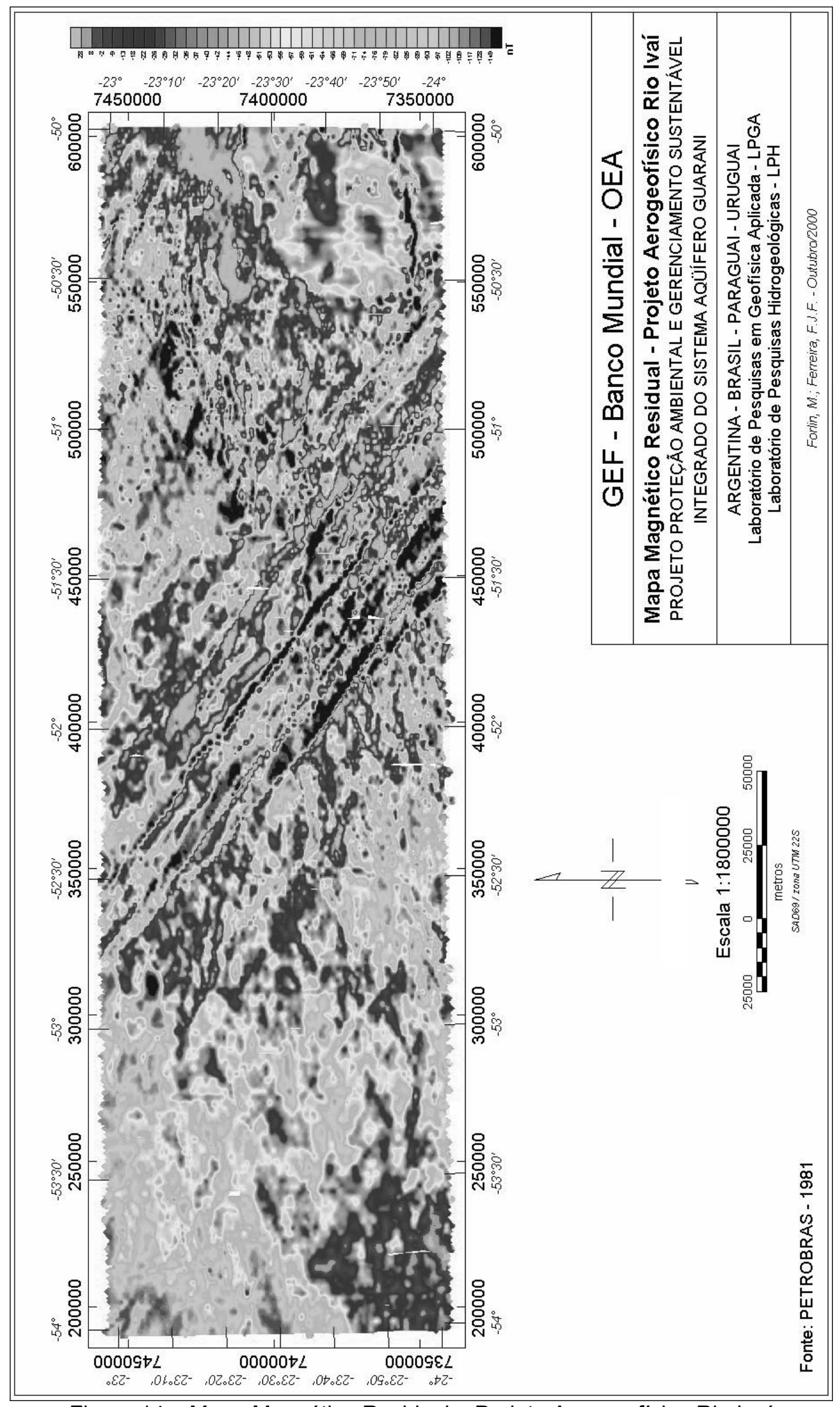

Figura 14 - Mapa Magnético Residual - Projeto Aerogeofísico Rio Ivaí 


\section{RECOMENDAÇÕES}

O desenvolvimento dos modelos hidrogeológico e exploratório para o SAG deve incluir as rochas sedimentares arenosas e as rochas vulcânicas fraturadas, com enfoque principal nos aspectos estruturais e suas relações com as zonas de recarga e descarga. A partir de dessa premissa, torna-se fundamental estabelecer uma estratégia de exploração, envolvendo fatores técnico-científicos (geológicos, geofísicos, hidroquímicos, etc) e sócioeconômicos, que permita definir os locais mais propícios para extração de água subterrânea e, ao mesmo tempo, possibilite um gerenciamento que compatibilize tal produção com o uso e proteção do SAG. De modo geral, para que tais metas sejam alcançadas, devem ser necessariamente conhecidos os controles geológicos na dinâmica hidrológica do SAG (padrões de fluxo, quantificação volumétrica/vazão e qualidade da água) e qual a sua compartimentação geométrica (blocos ou unidades que contêm aspectos diferenciados nesta dinâmica). Quanto ao aspecto da compartimentação, entende-se ser esta uma etapa fundamental na aquisição de novos conhecimentos a respeito do SAG, haja vista a existência de particularidades quanto à vazão e qualidade da água, que certamente refletem interligações controladas por grandes alinhamentos e/ou conjuntos de diques de diabásio. Aspectos petrográficos, tais como cimentação diferenciada e variações faciológicas, também têm sua importância relativa, porém a lacuna é muito maior no sentido da geologia estrutural do aqüífero.

A Bacia do Paraná apresenta o registro de várias fases deformacionais superpostas e recorrentes, como evidenciado em inúmeros trabalhos já publicados. Constata-se que as fases de deformação condicionaram o desenvolvimento de um arcabouço tectônico razoavelmente complexo, que afeta a grande maioria das seqüências deposicionais preservadas. Não obstante, faltam trabalhos direcionados ao estudo de aqüíferos fraturados na Bacia (basaltos da Formação Serra Geral) e ao conhecimento acerca do papel que os grandes lineamentos e diques de diabásio exercem na modificação do fluxo nos aqüíferos arenosos (formações Pirambóia, Botucatu e unidades correlatas nos países vizinhos). Dessa forma, é de grande importância um estudo que considere os aspectos sedimentológicos do SAG, porém não deixando de lado a compartimentação estrutural como controladora dos padrões de fluxo e zonas de recarga e escape na bacia. A compartimentação da Bacia do Paraná em blocos tectônicos separados por falhas é refletida também na compartimentação do SAG. Isto é constatado pela contaminação de alguns poços restritos aos aqüíferos fraturados, os quais contêm elementos que indicam a comunicação com os aqüíferos arenosos.

Recomenda-se, portanto, entender a contaminação e posicionar as zonas intermediárias de descarga, principalmente para o território brasileiro. Da mesma forma, faz-se necessário construir uma base de dados que propicie o gerenciamento sustentável do SAG, passando necessariamente pela determinação dos padrões de fluxo e de conexão entre aqüíferos. Tal objetivo só será alcançado caso sejam considerados os aspectos estruturais, normalmente negligenciados nos estudos já desenvolvidos sobre o SAG.

Conforme explicitado no texto, não obstante exista uma cobertura aeromagnetométrica de reconhecimento da Bacia do Paraná no Brasil, os dados foram apenas integrados preliminarmente, necessitando de uma avaliação crítica quanto a qualidade dos mesmos, bem como sua integração digital, no sentido de gerar uma base de dados que permita interpretações que subsidiem a seleção de áreas alvo. A proposta de realização de levantamentos aerogeofíscos de alta resolução é de fundamental importância no sentido de caracterizar áreas permeadas por diques de diabásio, os quais são condicionantes da compartimentacão do Sistema Aqüífero Guarani. Os dados gravimétricos já existentes também passarão por uma avaliação crítica e orientarão detalhamentos das áreas selecionadas. Por fim, os trabalhos geofísicos terrestres propostos, com o emprego dos equipamentos existentes em várias instituições que poderiam contribuir com o projeto, bem como aqueles a serem adquiridos no âmbito deste projeto, visam obter informações detalhadas das áreas selecionadas pela integração dos dados geofísicos, geológicos e hidrogeológicos com 0 objetivo de aprofundar 0 
Rev. Águas Subterrâneas nํ 17/ Maio 2003.

conhecimento sobre a geometria e a dinâmica do mencionado sistema aqüífero. 


\section{REFERÊNCIAS BIBLIOGRÁFICAS}

Almeida, F.F.M. 1980. Tectônica da Bacia do Paraná no Brasil. São Paulo, IPT, 187p. il. Bibliografia. Relatório IPT, 14091, Paulipetro(circulação restrita).

Almeida, F.F.M. 1983. Relações tectônicas das rochas alcalinas mesozóicas da região meridional da plataforma sulamericana. Revista Brasileira de Geociências, v.13, p.139-158.

Amaral, G.; Cordani, U.G.; Kawashita,K. Reynolds, J.H. 1966. Potassium-argon dates of basaltic rocks from southern Brasil. Geochimica et Cosmochimica Acta, v.30, p.139-158.

Amaral, G.; Crósta, A.P. 1983. Comportamento estrutural e estratigráfico dos diferenciados ácidos da Formação Serra Geral na porção sul da Bacia do Paraná. Atas do $4^{\circ}$ Simpósio Regional de Geologia, Núcleo São Paulo, Sociedade Brasileira de Geologia, SBG, São Paulo, p.197-210.

Araújo, L.M.; França, A.B.; Potter, P.E. 1995. Aqüífero Gigante do Mercosul no Brasil, Argentina, Paraguai, e Uruguai: mapas hidrogeológicos das formações Botucatu, Pirambóia, Rosário do Sul, Buena Vista, Misiones e Tacuarembó. Universidade Federal do Paraná (UFPR) e Petróleo Brasileiro S.A. (Petrobrás), 16p. e anexos.

Caetano-Chang, M. R.; Wu, F. T. 1992 Bacia do Paraná: Formações Pirambóia e Botucatu. In: Congresso brasileiro de Geologia, 37, São Paulo, SBG, Roteiro de Esxcursão, 19p.

Cordani, U.G.; Neves, B.B.B.; Fuck, R.A.; Porto,R.; Tomaz Filho, A.; Cunha, F.M.B. 1984. Estudo preliminar de integração do Pré-Cambriano com os eventos tectônicos das bacias sedimentares brasileiras. Boletim Ciência-TécnicaPetróleo, Seção Rio de Janeiro, Exploração de Petróleo, Publicação $\mathrm{n}^{\circ}$ 15, Petrobrás-Cenpes-Sintep, 70p.

Davino, A.; Sinelli, A.; Souza, Correia, C.T. 1982. Diabásios na região nordeste da Bacia do Paraná. Anais do XXXII Congresso Brasileiro de Geologia, Sociedade Brasileira de Geologia, SBG, Salvador, v.4, p.1736-1744.

Faisntein, R.; Gregory-Sloan, J.; Christie, P. 1998. Hydrocarbon plays off the Brazilian coast: West Africa's mirror image. In: Schlumberger. Searching for Oil and Gas in the Land of Giants. Schlumberger, Chapter 5, p. 78-88.

Ferreira, F.J.F.; Moraes, R.A.V.; Ferrari, M.P.; Vianna, R.B. 1981. Contribuição ao Estudo do Alinhamento Estrutural de Guapiara. In: Simpósio Regional de Geologia, 3., Curitiba, 1981. Atas. Curitiba, SBG, Núcleo São Paulo, v.1, p. 226-240.

Ferreira, F.J.F. 1982a. Integração de Dados Aeromagnéticos e Geológicos: Configuração e Evolução do Arco de Ponta Grossa. Dissertação de Mestrado. Instituto de Geociências da Universidade de São Paulo (USP), 170p. (circulação restrita).

Ferreira, F.J.F. 1982b. Alinhamentos Estruturais-Magnéticos da Região CentroOriental da Bacia do Paraná e seu Significado Tectônico. In: Geologia da Bacia do Paraná - Reavaliação da Potencialidade e Prospectividade em Hidrocarbonetos. Paulipetro, Consórcio CESP-IPT, p. 144-166.

Fúlfaro, V.J.; Saad, A.R.; Santos, M.V.; Vianna, R.B. 1982. Compartimentação e evolução tectônica da Bacia do Paraná. Revista Brasileira de Geociências, v.12, p.590-610.

Gama Jr. E.; Bandeira, A.N.; França, A.B. 1982. Distribuição espacial e temporal das unidades litoestratigráficas Paleozóicas na parte central da Bacia do Paraná. Revista Brasileira de Geociências, v.12, p.578-589.

Mantovani, M.S.M.; Cordani, U.G.; Roisenberg, A. 1985. Geoquímica isotópica em vulcânicas ácidas da Bacia do Paraná e implicações genéticas associadas. Revista Brasileira de Geociências, v.15, p.61-65.

Matos, S. L. F.; Coimbra, A. M. 1997 Sucessão de fácies na Camada Porangaba, Grupo Passa Dois, Estado de São Paulo. Rev. Bras. Geoc. SBG, 27(4):377-386

Mezzalira, S. (org.) 1981 Léxico estratigráfico do Estado de São Paulo. Bol. Instituto Geológico, São Paulo, 5, $161 \mathrm{p}$.

Milani, E. J.; França, A. B. Schneider, R. L. 1994 Bacia do Paraná. Bol. Geoc. Petrobrás, Petrobrás, 8(1):69-82

Milani,E.J., Ramos,V.A. 1998. Orogenias Paleozóicas no Domínio Sul-Ocidental do Gondwana e os Ciclos de Subsidência da 
bacia do Paraná. Revista Brasileira de Geociências, 28(4):473-484.

Milani,E.J. 1997. Evolução TectonoEstratigráfica da Bacia do Paraná e Seu Relacionamento com a Geodinâmica Fanerozóica do Gondwana Sul-Ocidental. Tese de Doutoramento. UFRGS. 254 p. + volume de anexos

Milani, E.J.; Thomaz Filho, A. 2000. Sedimentary Basins of South America. In: U.G. Cordani; E.J. Milani; A. Thomaz Filho; D.A. Campos. Tectonic Evolution of South America, Edição Especial do $31^{\text {st }}$ International Geological Congress, p. 389-449.

Northfleet, A.R.; Medeiros, R.A.; Mühlmann, H. 1969. Reavaliação dos dados geológicos da Bacia do Paraná. Boletim Técnico da Petrobrás, v.12, $n^{\circ} 3$, p. 291346.

Paulipetro 1981. Relatório de Atividades 1979/1981, 59 pp.

Paraguassu, A. B. 1968 Contribuição ao estudo da Formação Botucatu: sedimentos aquosos, estruturas sedimentares e silicificação. Tese de doutorado apresentada a E. E. S. C. da Universidade de São Paulo, São Carlos, 131p.

Proyeto PAR 83/005. 1986. Mapa Geológico del Paraguay 1:1.000.000 - P.N.U.D. C.N.D.I.Ch /M.D.N., mapa y texto explicativo inedito, Asunción.

Sanford, B.; V.; Lange, F.W. 1960. Basinstudy approach to oil evaluation of Paraná miogeosyncline, south Brazil. American Association of Petroleum Geologists Bulletim, v.44, p. 1316-1370.

Schneider, R.L.; Mühlmann, H.; Tommasi, R.A.; Medeiros, R.A.; Daemon, R.F.; Nogueira, A.A. 1974. Revisão estratigráfica da Bacia do Paraná. Anais do XXVIII Congresso Brasileiro de Geologia, Sociedade Brasileira de Geologia, SBG, Porto Alegre, v.1, p.4165.

Schneider, R. L.; Muhlmann, H.; Tommasi, E.; Madeiros, R. A.; Daemon, R. F.; Nogueira, A. A. 1974 Revisão estratigráfica da Bacia do Paraná. In: Congresso Brasileiro de Geologia, 28, Porto Alegre, SBG. Anais, 1:41-65

Schobbenhaus,C.;Lopes,R.C. (coord.) 1998. Mapa de Integração Geológica da bacia do Prata e Áreas Adjacentes. Escala 1:2.500.000. DNPM/CPRM.
Soares, P. C. 1975 Divisão estratigráfica do Mesozóico no Estado de São Paulo. Rev. Bras. Geoc., SBG, 5(4):229-251.

Soares, P.C. 1992. Tectônica Sinsedimentar Cíclica na Bacia do Paraná: Controles. Tese Apresentada À Ufpr, Departamento de Geologia, Curitiba/PR em Concurso para Professor Titular. 148 pp.

Soares, P.C.; Barcellos,P.E.; Csordas,S.M. 1982. Análise, interpretação e integração de lineamentos a partir de imagens (Radar-Landsat) e suas relações com a tectônica da Bacia do Paraná. São Paulo: Relatório RT-342/82, Paulipetro. Consórcio CESP/IPT.

Soares, P.C.; Barcellos, P.E.; Csordas, S.M.; Mattos, J.T.; Balieiro, M.G.; Meneses, P.R. 1982. Lineamentos em imagens Landsat e Radar e suas implicações no conhecimento tectônico da Bacia do Paraná. II Simpósio de Sensoriamento Remoto, CNPq-INPE, Brasília.

Velazquez, V.F. 1992. Província Alcalina Central, Paraguai Centro-Oriental: Aspectos Tectônicos, Petrográficos e Geocronológicos. Dissertação de Mestrado, Universidade de São Paulo, $119 \mathrm{pp}$.

Vieira, A.J. 1973. Geologia do centro e nordeste do Paraná e centro-sul de São Paulo. Anais do XXVII Congresso Brasileiro de Geologia, Sociedade Brasileira de Geologia, SBG, Aracaju, v.3, p.259-277.

Wu, F. T.; Caetano-Chang, M. R. 1992 Estudo mineralógico dos arenitos das formações Pirambóia e Botucatu no centro-leste do Estado de São Paulo. Rev. Inst. Geológico Est. S. Paulo, 13:5868

Zalán, P.V.; Conceição, J.C.J.; Astolfi, M.A.M.; Appi, V.T.; Wolff, S.; Vieira, I.S.; Marques, A. 1985. Estilos estruturais relacionados a intrusões magmáticas básicas em rochas sedimentares. Boletim Técnico da Petrobrás, v.28, p. 221-230.

Zalán, P.V.; Wollf, S.; Astolfi, M.A.M.; Vieira, I.S.; Conceição, J.C.J.; Appi, V.T.; Neto, E.V.S.; Cerqueira, J.R.; Marques, A. 1990. The Paraná Basin, Brazil. In: Interior Cratonic Basins, Leighton et. al. (editors), American Association of Petroleum Geologists Memoir 51, Chapter 33, p. 681-708. 